\title{
DESIGN BAGAN FISHING TOOL USING AUTOMATIC BASED SENSOR MAXSONAR ARDUINO-WR
}

\author{
Andi Maslan, Joni Eka Chandra, Cosmas Eko Suharyanto
}

\begin{abstract}
Indonesia is a Maritime country, consists of many islands from Sabang to Merauke. One of the islands is Riau Archipelago. The people of Riau Archipelago are livelihood as fishermen. Fishing Equipment used by fishermen still lags behind other countries that are geographically not maritime nations. Fishermen use a traditional set of fish traps made of light-mounted nets. In the process of catching fish, light instructors are required to collect fish that have positive phototoxic. Fish will gather under lights, then, the nets will be lifted manually by fishermen. The fishing process is less efficient. In this study, we try to create a modern technology by developing prototype, an applicable technology that can be applied for the fisherman. The protyotype developed in this study by making an Arduino-based automatic fish catcher using the Maxsonar-WR Sensor. Through the design stage, analysis and testing, the fishing prototype can do the fishing automatically so that easier job for the fisherman in his work.
\end{abstract}

Index Terms - Sonar, Arduino, Bagan, Sensor, Maritime

\section{INTRODUCTION}

A $S$ a maritime country, Indonesia is geographically composed of thousands of islands that spread from Sabang to Merouke. The income in the Fisheries sector is second only to the agricultural sector. Talking about fishing technology, the local fisherman is left behind from other countries that are geographically not maritime countries, so that the fishery industry is not optimal. Fishery industry revenues in Thailand and the Philippines, followed by Vietnam, is better than Indonesia, they managed to penetrate the international market.

Batam, one of the islands of the Riau Islands Province, is one of the areas with a large population of fishermen. However, they are traditional fisherman, using simple equipment for fishing. One of the traditional tools used for fishing is Bagan, a fish trap made by utilizing light abstrators from lights. Light instructors are used to invite fish that have positive phototaxis properties. Fish that are positive phototaxis will gather in the area around the lamp. The technology to be applied to this research is by creating an Arduino-based automated fish tool using Sonar system as a detection tool. Sonar system is able to detect the presence of existing seabed fish or in the catchment area.

In recent work, sonar sensors have been discussed in several studies, "Designing Sonar Transmitters for Submarine Detection Systems"; The research explains that Sound Navigation and Ranging (SONAR), is a detection technique using acoustic waves, in this case using water as a propagation medium [1].

- Andi Maslan Fakultas Teknik Putera Batam university, Indonesia,PH-+6281372117034.E-mail: lanmasco@gmail.com

- Joni Eka Chandra Fakultas Teknik Putera Batam University, Indonesia, PH-+6285655567040. E-mail jonicandra82@gmail.com

- Cosmas Eko Suharyanto Fakultas Teknik Putera Batam University, Indonesia, PH-+6285668174530. E-mail:

costmust@gmail.com
The SONAR system consists of a transmitter system in which there are wave generators, modulators, amplifiers, and projectors (electric-acoustic transducers), while on the receiver side consists of hydrophones (acoustic-electric transducers), filters, demodulators, amplifiers, signal processors and displays. The design of a communication system, as well as SONAR, begins with Link Budget transmission and underwater propagation that refers to the specified specifications. The Link Budget will calculate the need for acoustic power intensity on hydrophones, electrical losses in all electronic components, acoustic losses along the underwater transmission, and electrical conversion vibration losses to acoustic vibrations by projector and reverse conversion by hydrophones. This paper discusses the acoustic transmitter of the submarine detection sonar system. By adding factors derived from the link budget, the demand for acoustic power projected into the water can be determined. The projector's conversion factor determines the electrical power that must be incorporated on the projector by a sonar power amplifier. The carrier wave frequency is determined according to the range and depth.[2]

The same research has also been discussed by [3] entitled "Detecting Fish Existence Using Ultrasonic Sensor". From the experiments and analysis in outline Aim art AT200 can be used to detect the presence of fish below the water surface. Both the distance and the number of fish can be read although using calculations manusally, while for visualization of objects can be detected well in experiments using one and two objects. The result of object visualization is $69 \%$ and fFor distance visualization, can be read well on the object distance of five meters down. [3].

In another study, the use of sonar sensors in detecting fish and prototype fishing gear titled "Designing Prototype Automatic Fishing Machine Use Sonar Sensor" [4]. In this research, the design of prototype automated fish bagan using arduino uno R3 sonar sensor [5][6]. This automatic Bagan using 
the light as a phototaxis photovoltaic, and use the LvMaxsonar Ez sensor as a phototaxis fish arrival detection. In this design there is also a series of H-Bridge that serves to move the motor that serves to lower and pull the net. Test results without using water found that all parts of the system running well. The dc motor will decrease the typing net of the push button on tap and once the net reaches the specified depth the dc motor will stop then the sensor will begin to detect the phototactic fish coming to the light emitted just above the net, when the fish is detected by the sensor the dc motor will pull the net up [7].

The difference of this research is the type of Sonar Acoustics used. In the previous study, the design of a prototype automated Bagan using the Lv-Maxsonar Ez sonar sensor [8]. This automated Bagan uses light as a photovoltaic photovoltaic, and uses the Lv-Maxsonar Ez sensor as a phototactic fish arrival detector.

\section{RESEARCH METHOD}

Based on the design block diagram of the system in Figure 1, can be divided into three parts: the input section there is a maxsonar sensor as an object detector and ldr sensor as a detector of light, on the controller there arduino board which serves as a central controlling various peripherals, Output there are motors, lights and buzzer as actuator of detection result from sensor.

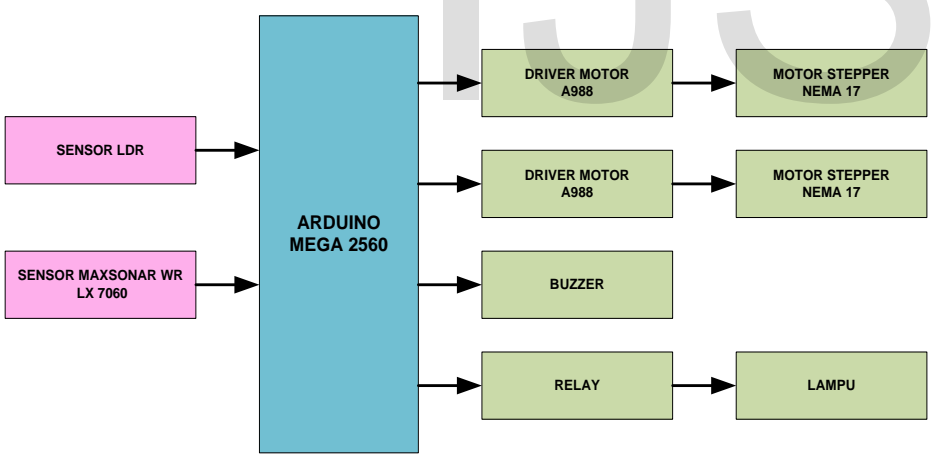

Figure 1. System Design Block Diagram

\subsection{Hardware Design}

The design of the hardware includes design of the Bagan prototype and design of prototype controller electronics Bagan as in Figure 2 and Figure 3. The design of electronics hardware is assembled based on the design of the system divided into three important parts: the input, controller and output.

In the input section in the form of maxsonar sensor and ldr sensor, maxsonar sensor used is maxsonar xl 7060 sensor capable of operating inside and surface water so that the use of this sensor can be done on surface or in water, maxsonar $\mathrm{xl}$ 7060 sensor has object detection distance between $20-765 \mathrm{~cm}$. The detection process of maxsonar $x 17060$ sensor can be done analog or digital, maxsonar xl 7060 sensor only requires operational voltage 5 VDC which can be obtained directly from arduino board. As for the LDR sensor used is a LDR sensor module that can be set sensitivity level of the sensor to light and LDR sensor module. The process of detecting rays can be done analogue or digital, LDR sensors operate at a voltage of 3.3 - 5 VDC which can also be obtained directly from the arduino board.

The controller section uses a mord arduino mega 2560 as the control center of various peripherals, arduino mega 2560 using Atmega2560 microcontroller and has 54 digital input or output [5]. 14 pins are used for PWM output and 16 pins are used as analog inputs, 4 pins for UART, $16 \mathrm{MHz}$ crystal oscillator, USB connection, ICSP header jack header and button research. This module can operate at a voltage of 6 20VDC.

At the output, there are two bipolar stepper motors type nema 17 as the actuator output from maxsonar xl 7060 sensor, to adjust the direction and speed of rotation of this stepper motor then used A988 stepper motor driver as actuator which in its use very easy and this driver operate on voltage 3 - 5.5 VDC. The lamp as an output of the LDR sensor requires a 1 channel Relay as a switch to switch on and off the lamps that have AC voltage sources. While Buzzer is also the output of the sensor maxsonar xl 7060 and buzzer type used is a buzzer that can operate on tengan 3 - 24 VDC.

To start the whole set of electronic hardware as the controller of the bagan prototype required power supply, the power supply is the most important part in the design of this electronic hardware, the required power supply of this hardware component 3.3 - 5 VDC which the average is obtained from the arduino mega 2560 board. For that the power supply used in the form of adaftor 12 VDC with output current of $2000 \mathrm{~mA}$ which is connected with arduino mega2560 power jack that can operate at $5-20$ VDC voltage, and actuator motor driver A988 besides get power supply 5 VDC also requires a 12 VDC power supply with a minimum current of at least $1200 \mathrm{~mA}$ to drive a stepper motor obtained from 12 VDC displays with a $2000 \mathrm{~mA}$ current.

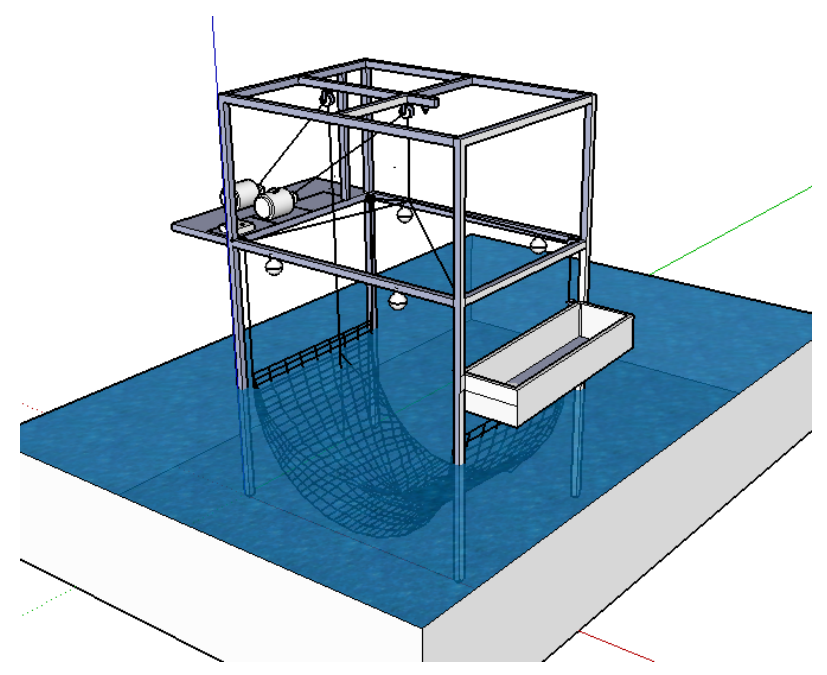

Figure 2. Prototype Design Model of the fish Bagan 


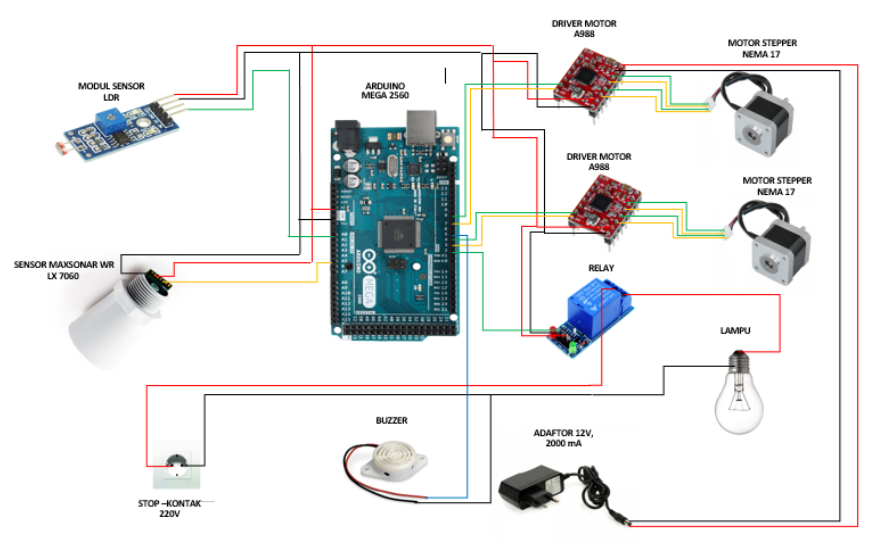

Figure 3. Hardware Design Components

\subsection{Software Design}

This hardware design using arduino mega2560 board as the main controller, will not work if not accompanied by software designed as controller of system as a whole. This software acts as a controller and connector that regulates the steps to be performed by arduino mega2560 board microcontroller on the whole system created. The software is designed using a simplified $C$ language. Programs created for arduino mega2560 have the following functions:

1. The maxsonar sensor WR XL 7060 and LDR provide input to arduino mega2560

2. Processing input signal from Maxsonar WR XL 7060 sensor and LDR sensor

The output value of the maxsonar sensor WR XL 7060 will be received by the arduino mega2560 and arduino mega2560 input pin will give the output value in the form of sound on the buzzer and also will be the input value for the A988 motor driver which will then adjust the direction of rotation and speed of stepper motor, While the output value of the LDR sensor received by the arduino mega 2560 input pin will provide an output value which will be the input value for the relay which will then turn on and off the lamp.

\section{RESULTS AND ANALYSIS}

\subsection{Hardware Testing}

After the design of hardware and software, we enter the next stage of testing and analysis of hardware (prototype). The hardware testing phase (prototype) of the tool is a part that must be done with the aim to find out whether the electronic components of the compilers of the hard struggle (Prototype) can work and to know the characteristics of the components of the hardware compiler.

\subsection{Testing Goal}

The purpose of testing hardware (prototype) in this study is to determine whether the prototype works in accordance with the description of its work and the design has been made.

\subsection{The component and equipment used}

The components and equipment used in testing the hardware (prototype) of this study can be seen in Table 1:

Table 1. Components and testing equipment

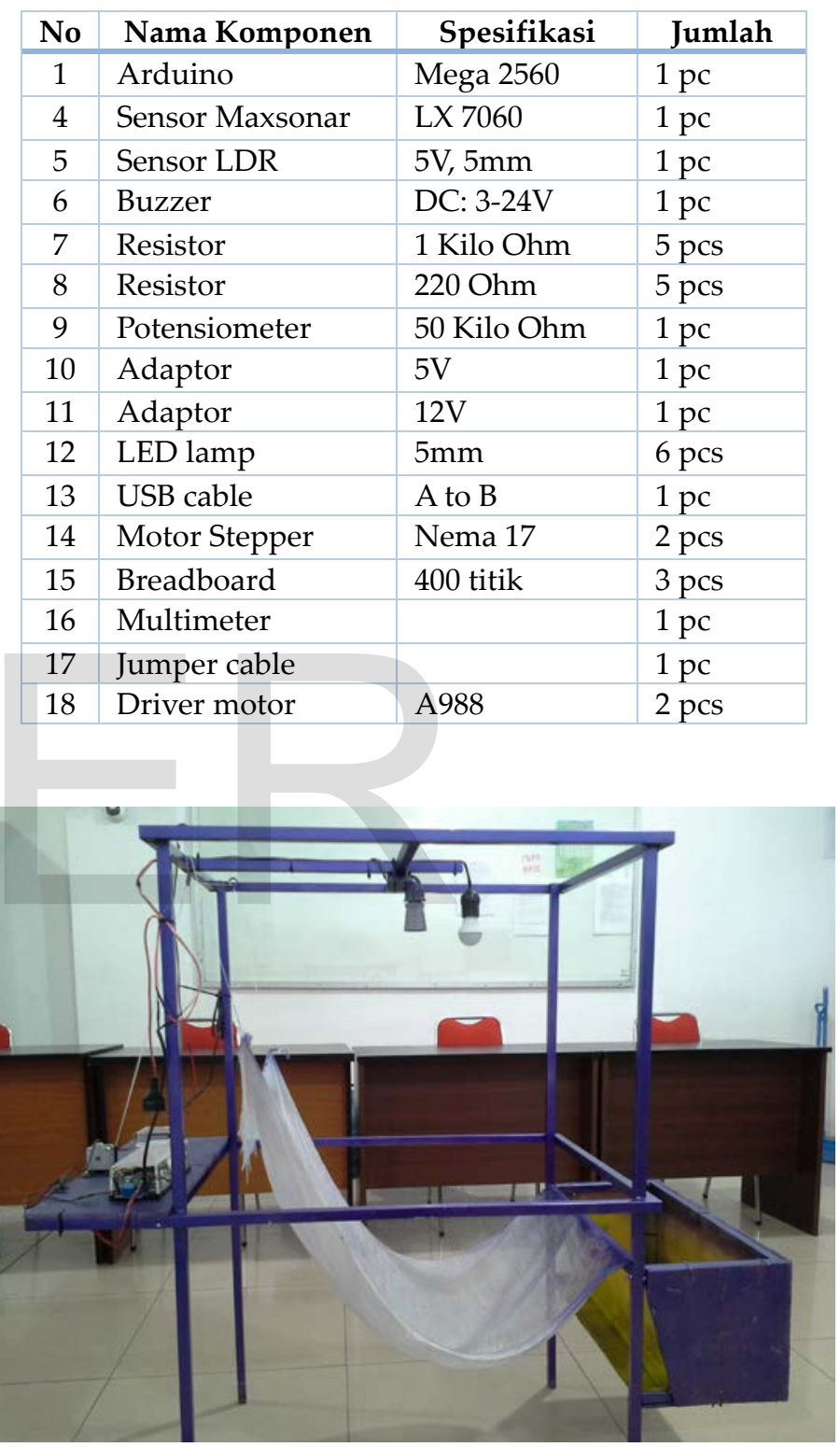

Figure 5. Bagan Protortype Side View

\subsection{Testing Procedure}

The stages in conducting testing in this study as follows:

1. Make installation of the required components according to the circuit hardware (prototype) as in Figure 1.

2. Connect arduino mega2560 and arduino uno board with laptop using USB cable and make sketch pro- 
gram overall prototype and upload sketch to board arduino mega and arduino uno

3. Disconnect the USB cable from the arduino mega and arduino uno boards and then provide voltage to both arduino boards sourced from $12 \mathrm{~V}$

4. After the prototype lights up, the next step is to turn on and off the lights as a source of sunlight when the lights are turned on then the LDR sensor will detect the light of the lamp as the LDR sensor greater resistance that causes the light as an output indicator of the LDR sensor will die and vice versa if Lights off.

5. Then put an object under the ultrasonic sensor module maxsonar WR XL 7060 then shift the object's pesisi until the green indicator lights up and buzzer sounds (indicates the receiver works), then stepper motors will move rotate move the net up to the top as well as the object Which is detected into the container for a few minutes and then the stepper motor rotates in the opposite direction to lower the net to its original position until the red indicator light is on, indicating that no object is detected again under the maxsonar WR XL 7060 sensor.

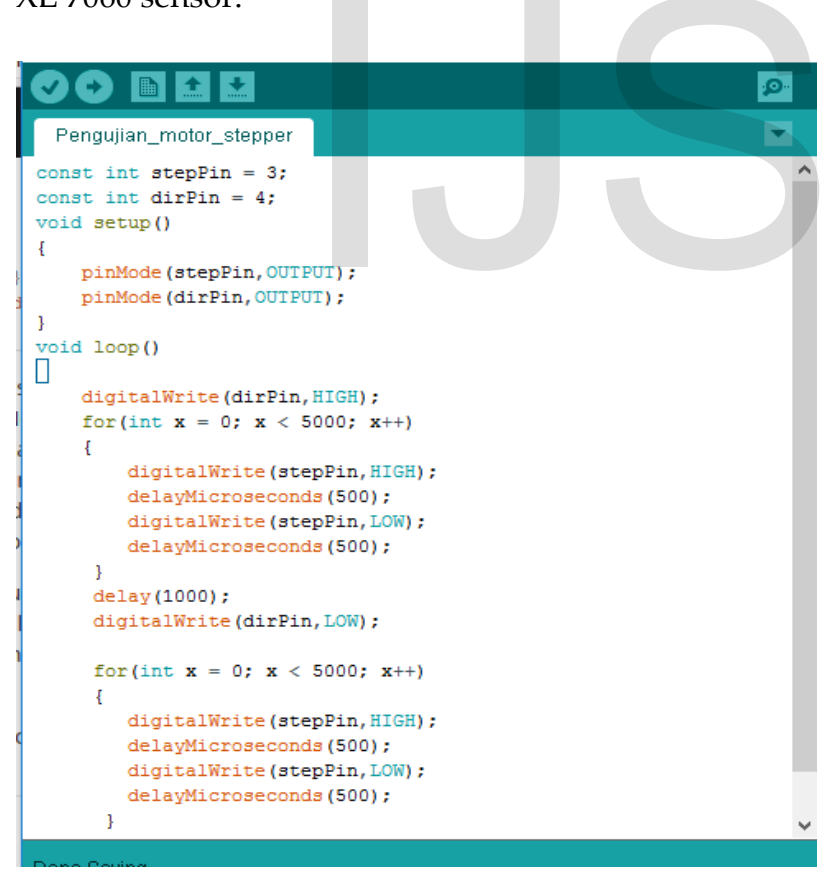

Figure 6. Sketch Stepper Motor Testing Program

\subsection{Measurement of Maxsonar WR XL 7060 sensor circuit and LDR sensor}

Output results from maxsonar sensor measurements of WR XL 7060 and LDR sensors shown in Table 2 and 3:
Table 2. Output Measurements of Maxsonar WR XL 7060 Sensor Voltage

\begin{tabular}{|l|l|l|}
\hline No & \multicolumn{1}{|c|}{ Sensor Treatment } & \multicolumn{1}{c|}{ Voltage } \\
\hline 1 & No Object detected & $4,8 \mathrm{~V}$ \\
\hline 2 & Object detected & $1,3 \mathrm{~V}$ \\
\hline
\end{tabular}

Tabel 3. Output Measurement of LDR Sensor Voltage

\begin{tabular}{|l|l|l|}
\hline State & Vin & Vout \\
\hline Bright & & $4,2 \mathrm{~V}$ \\
\hline Dark & \multirow{2}{*}{$5 \mathrm{~V}$} & $1,7 \mathrm{~V}$ \\
\cline { 1 - 1 } & &
\end{tabular}

\section{CONCLUSION}

Bagan Prototype can work if the fish pass through a net detected by the Maxsonar WR XL 7060 Sensor. The Maxsonar WR XL 7060 sensor works because the system uses an Arduino-based microcontroller. Automatic fish catchers can provide an indicator or sound if it has detected fish successfully, then stepper motors can lift, drop and pour fish into the shelter and this automatic bagan can ease the work for fishermen who do fishing.

\section{REFERENCES}

[1] E. N. De Souza, K. Boerder, S. Matwin, and B. Worm, "Improving fishing pattern detection from satellite AIS using data mining and machine learning," PLoS One, vol. 11, no. 7, 2016.

[2] S. Ismail, D. Permana, and E. J. Pristianto, "Perancangan Pemancar Sonar Untuk Sistem Pendeteksi Kapal Selam," Pros. InSINas 2012, p. HK-21HK-24, 2012.

[3] S. S. Haryono, Andreas Setiawan, "Pendeteksi Keberadaan Ikan Menggunakan Sensor Ultrasonik," J. Sains Mat., vol. 3, no. Prototype bagan penangkap ikan dapat melakukan penangkapan ikan jika ikan melewati jaringan yang terdeteksi oleh sensor Motor DC dapat melakukan gerak bolak balik untuk mengangkat dan menurunkan jaringan ikan Bagan Otomatis Berbasis Mikrokontroler Atmega8, pp. 7-25, 2013.

[4] B. Zion, A. Barki, J. Grinshpon, L. Rosenfeld, and I. Karplus, "An automatic fishing machine based on acoustic conditioning," Aquac. Eng., vol. 45, no. 2, pp. 87-91, 2011.

[5] Y. A. Tuwaidan, E. V. C. Poekoel, D. J. Mamahit, and M. Eng, "Rancang Bangun Alat Ukur Desibel ( dB ) Meter Berbasis Mikrokontroler Arduino Uno R3," E-Jurnal Tek. Elektro dan Komput., vol. 1, no. 1, pp. 37-43, 2015.

[6] M. G. Simanjuntak, "Perancangan Prototipe Smart Building Berbasis Arduino UNO," Singuda Ensikom, vol. 2, no. 2, pp. 6-31, 2013.

[7] Z. Abidin, "PEMBUATAN PROTOTIPE BAGAN PENANGKAP IKAN," Bandar IT, 2015.

[8] A. Burguera, Y. González, and G. Oliver, "Sonar sensor models and their application to mobile robot localization," Sensors (Basel)., vol. 9, no. 12, pp. 1021743, 2009. 